\title{
Publisher Correction to: An economical and highly adaptable optogenetics system for individual and population-level manipulation of Caenorhabditis elegans
}

\author{
M. Koopman*, L. Janssen and E. A. A. Nollen*
}

Publisher Correction to: BMC Biol 19, 170 (2021)

https://doi.org/10.1186/s12915-021-01085-2

Following publication of the original article [1], the authors noted that incorrect Additional files were published, due to a typesetting mistake. The correct version of the single Additional file for this article (Additional file 1) is attached to this Publisher Correction and original article has been updated.

The publisher apologises to the authors and readers for the inconvenience caused by the error.

\section{Supplementary Information}

The online version contains supplementary material available at https://doi. org/10.1186/s12915-021-01152-8.

Additional file 1.

Published online: 27 September 2021

\section{Reference}

1. Koopman, et al. An economical and highly adaptable optogenetics system

for individual and population-level manipulation of Caenorhabditis elegans. BMC Biol. 2021;19:170. https://doi.org/10.1186/s12915-021-01085-2.

The original article can be found online at https://doi.org/10.1186/s12915021-01085-2.

* Correspondence: m.koopman@umca.nl; e.a.a.nollen@umca.nl European Research Institute for the Biology of Ageing, University of Groningen, University Medical Center Groningen, Groningen, The Netherlands

C C The Author(s). 2021 Open Access This article is licensed under a Creative Commons Attribution 4.0 International License, which permits use, sharing, adaptation, distribution and reproduction in any medium or format, as long as you give appropriate credit to the original author(s) and the source, provide a link to the Creative Commons licence, and indicate if changes were made. The images or other third party material in this article are included in the article's Creative Commons licence, unless indicated otherwise in a credit line to the material. If material is not included in the article's Creative Commons licence and your intended use is not permitted by statutory regulation or exceeds the permitted use, you will need to obtain permission directly from the copyright holder. To view a copy of this licence, visit http://creativecommons.org/licenses/by/4.0/ The Creative Commons Public Domain Dedication waiver (http://creativecommons.org/publicdomain/zero/1.0/) applies to the data made available in this article, unless otherwise stated in a credit line to the data. 